\title{
Nietypowa fala zwrotna po złożonym zabiegu naprawczym zastawki mitralnej
}

\author{
Unusual regurgitant jet after complex mitral repair
}

\author{
Katarzyna Wdowiak-Okrojek, Ewa Szymczyk, Piotr Lipiec, Jarosław D. Kasprzak \\ Katedra i Klinika Kardiologii Uniwersytetu Medycznego w Łodzi
}

Pacjent w wieku 59 lat ze stabilną chorobą wieńcową w II klasie Canadian Cardiovascular Society (CCS) oraz ciężką niedomykalnością zastawki mitralnej na podłożu wypadania tyInego płatka został poddany planowemu zabiegowi operacyjnemu, polegającemu na wszyciu pomostu żylnego do prawej tętnicy wieńcowej (choroba jednonaczyniowa) oraz jednoczasowej plastyce zastawki mitralnej. W badaniu echokardiograficznym przed operacją stwierdzano wypadanie segmentu P2 oraz częściowo P3 tylnego płatka zastawki mitralnej, bez cech zerwania strun ścięgnistych z istotną ekscentryczną falą zwrotną (ERO 0,4 cm², RVOL $91 \mathrm{ml}$ ); wymiar pierścienia mitralnego wynosił $35 \mathrm{~mm}$, bez innych istotnych nieprawidłowości morfologicznych serca. Zabieg zastawkowy obejmował kwadrantektomię P2, plikację ściany przedsionka oraz wszycie pierścienia Carpentier Physio $30 \mathrm{~mm}$. Okres okołooperacyjny był niepowikłany. W kontrolnym przezklatkowym badaniu echokardiograficznym (TTE, transthoracic echocardiography) 3 miesiące po operacji zaobserwowano pod płatkami mitralnymi szeroką falę zwrotną, w ocenie ilościowej o parametrach wskazujących jednak na jej umiarkowany stopien. Nie obserwowano skurczowego odwracania przepływu w żyłach płucnych, natomiast wizualnie talia fali zwrotnej w TTE obejmowała całą szerokość pierścienia (ryc. 1A). Wobec niejasności w ocenie naprawionej zastawki mitralnej wykonano badanie przezprzełykowe. Pomiar metodą Dopplera fali ciągłej wykazał typowe wartości po anuloplastyce; średni gradient przezzastawkowy wynosił 4,5 mm Hg, a maksymalna prędkość 1,5 m/s (ryc. 1B). Uwidoczniono także pozapierścieniowe ujście fali zwrotnej perforację nasady płatka tylnego w okolicy segmentu P2 (ryc. 1C). Badanie trójwymiarowe pozwoliło jednoznacznie uwidocznić wąską falę zwrotną praktycznie równoległą do płaszczyzny pierścienia, bez istotności hemodynamicznej (szerokość ujścia ok. $13 \mathrm{~mm}$ - ryc. 1D, E). Uzyskane obrazy uzasadniły zakwalifikowanie chorego do dalszego leczenia zachowawczego.

Leczenie operacyjne zespołu Barlowa jest zróżnicowane zależnie od morfologii wady i może obejmować kilka technik operacyjnych, takich jak: repozycja mięśnia brodawkowatego (w razie konieczności z repozycją strun ścięgnistych), skracanie strun ścięgnistych, implantacja goreteksowych strun ścięgnistych, resekcja nadmiarowej tkanki płatka (sliding plasty) - polegająca na odłączeniu podstawy płatka od pierścienia, wycięciu nadmiaru i ponownym jego zeszyciu z jednoczasowym zwężeniem pierścienia, resekcja trójkątna lub kwadrantektomia, resekcja edge-to-edge, plastyka/resekcja komisur, dekalcyfikacja pierścienia oraz wszycie pierścienia mitralnego [1-3]. W omawianym przypadku prawdopodobnie podczas kwadrantektomii/plikacji ściany przedsionka pozostała niewielka, niezszyta przestrzeń pozapierścieniowa powstała podczas plikacji płatka tylnego, dająca obraz nietypowej zewnątrzpierścieniowej fali zwrotnej, sugerujący znaczną niedomykalność mitralną, właściwie zinterpretowany dzięki obrazowaniu 3D z dokładną oceną ujścia i kierunku fali zwrotnej w wolumetrycznym zbiorze danych.
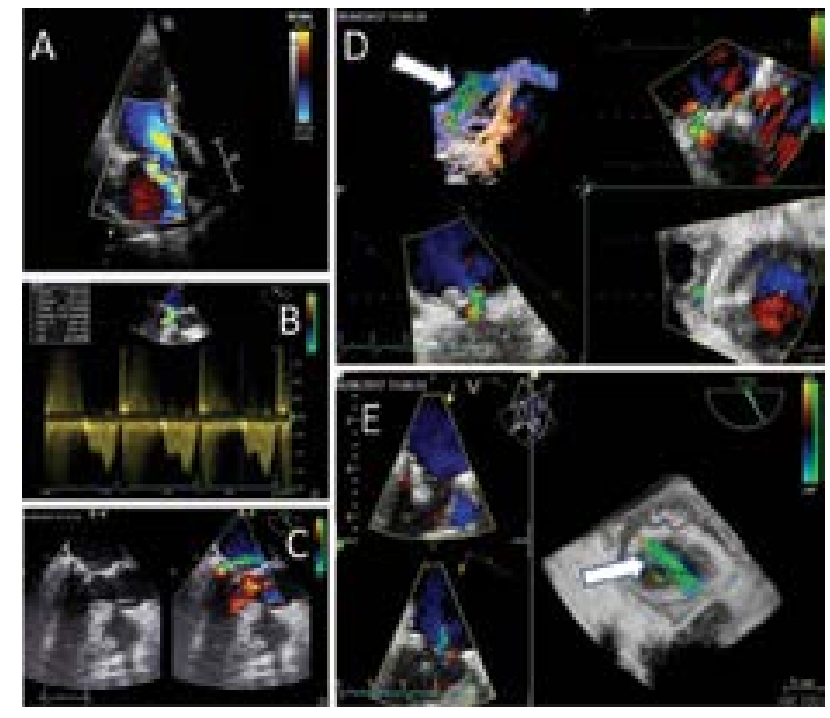

Rycina 1A-E. Ocena zastawki mitralnej po zabiegu naprawczym; A, B. Echokardiografia przezklatkowa: A. Fala zwrotna mitralna zarejestrowana po zabiegu naprawczym; B. Pomiar prędkości i gradientów przez zastawkę mitralną; C-E. Echokardiografia przezprzełykowa: C. Pozapierścieniowe źródło fali zwrotnej; D, E. Uwidocznienie kształtu i przebiegu fali zwrotnej w obrazowaniu trójwymiarowym

\section{Piśmiennictwo}

1. David TE, Ivanov J, Armstrong S, et al. A comparison of outcomes of mitral valve repair for degenerative disease with posterior, anterior, and bileaflet prolapse. J Thorac Cardiovasc Surg. 2005; 130(5): 1242-1249, doi: 10.1016/j. jtcvs.2005.06.046, indexed in Pubmed: 16256774.

2. Castillo JG, Anyanwu AC, Fuster V, et al. A near $100 \%$ repair rate for mitral valve prolapse is achievable in a reference center: implications for future

guidelines. J Thorac Cardiovasc Surg. 2012; 144(2): 308-312, doi: 10.1016/j. jtcvs.2011.12.054, indexed in Pubmed: 22698565

3. Castillo JG, Solís J, González-Pinto A, et al. [Surgical echocardiography of the mitral valve]. Rev Esp Cardiol. 2011; 64(12): 1169-1181, doi: 10.1016/j.recesp.2011.06.025, indexed in Pubmed: 22032935.

Adres do korespondencji: dr n. med. Katarzyna Wdowiak-Okrojek, Katedra i Klinika Kardiologii, Uniwersytet Medyczny w Łodzi, Kniaziewicza 1/5,

91-347 Łódź, tel. 4225162 16, e-mail: kwdowiakokrojek@gmail.com 